\title{
Relationship between Depressive Symptoms and Life Satisfaction Among University Students
}

\author{
Asra BABAYIĞIT ${ }^{1}$, Zihniye OKRAY $^{2}$
}

\begin{abstract}
The aim of the study is to investigate the depressive symptoms and life satisfaction among the university students in TRNC. The study also investigates the relationship between depressive symptoms and life satisfaction. The data of the study was collected in February 2016. The study consists of 50 university students. Participants were selected using convenience sampling method. The research's survey questionnaire was administered by face to face interviews. Questionnaire includes socio-demographic information form, Beck Depression Inventory and Life Satisfaction Scale. Descriptive statistical methods (mean, standard deviation), the one-way ANOVA and t-test analysis was used for comparisons of qualitative data. Study shows no significant relationship between depression and demographic variables. Only academic performance and life satisfaction's relationship was found as statistically meaningful as many other studies found the same parallel results. Depression is a growing problem throughout the world. Despite it is very common, most people do not perceive and accept depression as an illness. Non-treated depression can reach to severe levels and severe level of depression may lead to suicidal attempts. The importance of depression should be underlined because of its harmful consequences.
\end{abstract}

Key Words: Depression, Life Satisfaction, University Students.

\section{Üniversite Öğrencilerinde Depresif Belirtiler ve Yaşam Doyumu Arasındaki İlişki}

Özet: Çalışmanın amacı, KKTC'deki üniversite öğrencileri arasındaki depresif belirtilerin ve yaşam doyumunun araştırılmasıdır. Bunun yanında, depresif belirtiler ve yaşam doyumu arasındaki ilişki de araştırılmaktadır. Araştırmanın verileri Şubat 2016'da toplanmışıı. Çalışma 50 üniversite öğrencisinden oluşmaktadır. Katılımcılar uygun örnekleme yöntemi kullanılarak seçilmiştir. Araştırmanın anket fomu yüz yüze görüşmelerle uygulanmıştır. Anket sosyodemografik bilgi formu, Beck Depresyon Envanteri ve Yaşam Doyumu Ölçeğini içermektedir. Verilerin karşılaştırılmasında tanımlayıcı istatistiksel yöntemler (ortalama, standart sapma), tek yönlü ANOVA ve T testi analizi kullanılmıştır. Çalışma depresyon ve demografik değişkenler arasında anlamlı bir ilişki olmadığını göstermektedir. Yalnızca akademik performans ve yaşam memnuniyeti ilişkisi, diğer birçok çalışmayla paralel şekilde istatistiksel olarak anlamlı bulunmuştur. Depresyon tüm dünyada büyüyen bir sorundur. Çok yaygın olmasına rağmen, çoğu insan depresyonu bir hastalık olarak algılamamakta ve kabul etmemektedir. Tedavi edilmeyen depresyon şiddetli seviyelere ulaşabilir ve şiddetli depresyon seviyesi intihar girişimlerine neden olabilir. Depresyonun önemi, zararlı sonuçlarından dolayı vurgulanmalıdır.

Anahtar Kelimeler: Depresyon, Yaşam Doyumu, Üniversite Öğrencileri.

\footnotetext{
${ }^{1} \mathrm{MSc}$, Asra Babayiğit, Psychology Department, Arts and Science Faculty, Near East University,Nicosia-North Cyprus.

${ }^{2}$ Assoc. Prof. Zihniye Okray, Psychology Department, Arts and Science Faculty, European University of Lefke, North Cyprus.

Address of correspondence/ Yazışma adresi: MSc Asra Babayiğit, Near East University, Arts and Science Faculty, Psychology Department, Nicosia/TRNC. Email: asra.babayigit@ neu.edu.tr
}

Date of Received/ Geliş Tarihi: 14.04.2019, Date of Acceptance/ Kabul Tarihi: 30.04.2019

Citing/ Referans gösterimi: Babayiğit, A., Okray, Z. (2019). Relationship Between Depressive Symptoms and Life Satisfaction Among University Students. Cyprus Turkish Journal of Psychiatry and Psychology, 1 (1): 5-13. doi:10.35365/ctjpp.19.1.01 


\section{Introduction}

Depression is one of the most common psychiatric disorders (Murray and Lopez, 1996). When the individual and social costs due to the effects of depression are considered, it can be perceived as a serious public health issue (WH0, 2016). Depression is a mood disorder (Gündoğar, Gül, Uskun, Demirci, \& Keçeci, 2007, 14-27). Our emotional side is the most effective property in our all relationships and adaptations to the society (Öztürk \& Uluşahin, 2015, 261).

Life satisfaction is one of the most basic searches of the life and a judicial process related to the cognitive assessment about how extent the person is satisfied with their life (Erturan et. al., 2014, 172-6, Diener, 1984, 543-61). Ryan and his colleagues (1996) stated that behaviors related with autonomy, relevance, qualifications and other internal needs are increasing the life satisfaction.

There are many studies about life satisfaction with the university students and adolescents. For example, Young and Miller (1995) found that adolescent's perception for parent's attitude is related with life satisfaction. Another study, Moller (1996) made with South African students illustrates that economic level and ethnic properties are factors that are related with life satisfaction. In 2005, McKnight applied a study to university students and found that students which have contradictions with spirituality have lower life satisfaction (Dost, 2007).

Lately, it is observed that there is an increase in university students who are diagnosed or treated by the depression. Depression is the most serious emotional problem that students face with. University students maintain a balance between their own expectations and other people's (friend and family) expectations. In addition to this they try to discover themselves. During this discovery period there might be ups and downs in self-respect must adapt themselves to the changing environment and condition such as living place. Because of these factors and probability of negative life conditions there might be many stress factors. At last, university students become more vulnerable to psychological symptoms such as aggressiveness, anxious and depressive moods because of the uncertainty and adaption problems (Ceyhan, Ceyhan, \& Kurtyılmaz, 2009).

Life satisfaction is an important issue for every age groups and so for the university students. This can be related to living another place far away from their families. Most of the students go to a different city for their university education. They must adapt themselves to their new life and important changes. This may lead to bio-psychosocial problems (Sundriyal \& Koma, 2012, 33-36).

Depression is a growing problem in our country and throughout the world. Starting age of depression is also decreasing day by day. Depression is an important risk for the university students. This study aims to investigate the depressive symptoms and life satisfaction level among the university students in TRNC. The study tries to link life satisfaction level and depression with variables such as gender, economic support, academic performance and family relationships.

\section{Method}

\section{Participants and Procedure}

Data was collected in February 2016. Age range in this study is between 18 and 29. There are total 50 participants. $\% 23$ of the participants are female and $\% 27$ of the participants are male. None of the university students rejected to complete the survey. Study involves university students in TRNC. The convenience sampling method was used in the study. In this study, relational scanning model was used. Relational screening models are defined as research models aiming to determine the presence or degree of coexistence between two and more variables.

\section{Instruments}

Beck Depression Scale: It is consist of 21 indication of the depression. Emotional, cognitive and motivational symptoms which are observed in depression are measured. Every item represents a behavioral property belongs to depression. It is a selfreport using a four-point scale ranging which ranges from 0 (symptom not present) to 3 (symptom very intense). The test takes approximately 5 to 10 minutes for completion. Points are classified as; 0-13 no depression, 14-24 moderate depression, 25-63 severe depression. Accoring to the Tegin(1980) study, test-retest reliability of $\mathrm{r}=65$ and halving realibility of $r=78$. High scores was found in Tegin's study. The study which is done for the realibility and validity for beck depression scale realibility coefficient found as $\mathrm{r}=0.78$, and test-retest as $\mathrm{r}=0.65$ (Karaca \& Aşkın, 1995).

Life Satisfaction Scale: A 5-item scale designed to measure global cognitive judgments of one's life satisfaction. There are five statements that you may agree or disagree with. Using the 1 - 7 Likert scale below, indicate your agreement with each item by placing the appropriate number on the line preceding that item. Points are min 5, and $\max 35$. Scores 7 and 
below indicates a low satisfaction, 8-12 moderate and 13 and more high satisfaction. The low score indicates low life satisfaction. The scale is developed by the Diener in 1985 in order to determine the levels of life satisfaction. Diener stated cronbach alpha as .82 and tes re-test as 87 . The validity and realibility coefficient of the scale was made by Yetim to Turkish population in 1993. According to Yetim, r= .86 and re-test was found as $r=.73$ (Yetim, 2003).

Socio- Demographic Form: Consist of 17 questions which were prepared by the researchers. It tries to maintain some general information about the respondent and obtain information about the demographic variables such as age, gender, birth place and monthly income.

\section{Procedure of Data Collection}

Data collection was done using random sampling. Informed consent was given to make purpose of the study clear to the participants. The general instructions were explained to participants before completing the inventories. Help was provided to the participants in case they found any of the items difficult to comprehend.

\section{Data Analysis}

SPSS 22.0 (Statistical Programme for Social Sciences) package program was used for the data analysis. Along with descriptive statistical methods (mean, standard deviation), the one-way ANOVA, ttest analysis and Pearson correlation analysis were used for comparisons of qualitative data.

\section{Results}

In this study there are 23 female and 27 male participants. The age range of the participants is 18 28. Most of them (\%76) are born in Turkey and \%18 are born in TRNC. Only one of the participants was married and \%56 of them clarified that they are not in a relationship. The reason to stay at TRNC was mostly University (\%74) whereas \%22 of them was residents of TRNC. $\% 52$ of the sample is at their $3^{\text {rd }}$ class, $\% 34$ at $1^{\text {st }}$ class, $\% 10$ at $4^{\text {th }}$ class and $\% 4$ at $2^{\text {nd }}$ class. When we look at their income, \%36 of the sample have no income, \%36 have 1600 or under income. Only $\% 6$ of them stated that they have more then 3200 income. \%46 of them live with a friend, $\% 30$ with family and \%20 live alone. Most of participants (\%86) get their personal income through family support, only $\% 4$ of them claimed that they are working. Only \%18 of the sample rated their academic performance as moderate.

Table 1.Comparison of Mean Score of Beck Depression and Socio-demographic Characteristic of University Students in TRNC

\begin{tabular}{lll}
\hline Demographic variables & $\mathbf{m} \pm \mathbf{s d}(\mathbf{n})$ & F $(\mathbf{p})$ \\
\hline Gender & $29.30 \pm 6.03(\mathrm{n}=23)$ & $0.642(0.150)$ \\
Female & $32.33 \pm 8.52(\mathrm{n}=27)$ & \\
Male & $31.78 \pm 6.51(\mathrm{n}=9)$ & $0.456(0.637)$ \\
Birth Place & $31.05 \pm 7.91(\mathrm{n}=38)$ & \\
Cyprus & $27.00 \pm 6.93(\mathrm{n}=3)$ & \\
Turkey & & \\
England & $25.75 \pm 3.40(\mathrm{n}=4)$ & \\
Marital Status & $31.06 \pm 9.63(\mathrm{n}=18)$ & \\
Engaged & $21.32 \pm 7.08(\mathrm{n}=28)$ & $0.747(0.479)$ \\
In relationship & & \\
Not in relationship & $31.27 \pm 6.51(\mathrm{n}=11)$ & \\
Reason to be in TRNC & $31.19 \pm 7.98(\mathrm{n}=37)$ & \\
Native-born & $24.50 \pm 2.12(\mathrm{n}=2)$ & \\
University & $31.59 \pm 5.62(\mathrm{n}=17)$ & \\
Other & $34.00 \pm 15.56(\mathrm{n}=2)$ & \\
Class & $30.62 \pm 8.22(\mathrm{n}=26)$ & \\
$1^{\text {st }}$ & $29.20 \pm 9.01(\mathrm{n}=5)$ & \\
$2^{\text {nd }}$ & & \\
$3^{\text {rd }}$ & & \\
$4^{\text {th }}$ & &
\end{tabular}




\begin{tabular}{lll}
\hline Monthly income & $30.56 \pm 6.71(\mathrm{n}=18)$ & $0.691(0.562)$ \\
No income & $31.39 \pm 9.24(\mathrm{n}=18)$ & \\
1600 and below & $29.36 \pm 6.55(\mathrm{n}=11)$ & \\
$1600-3200$ & $36.33 \pm 4.51(\mathrm{n}=3)$ & \\
3200 or more & & \\
Whom they live & $33.40 \pm 10.70(\mathrm{n}=10)$ & \\
Alone & $31.07 \pm 5.38(\mathrm{n}=15)$ & \\
Mother/father/sibling & $29.74 \pm 7.61(\mathrm{n}=23)$ & \\
Friend & $31.50 \pm 0.71(\mathrm{n}=2)$ & \\
Other & & \\
Economic support & $35.50 \pm 7.78(\mathrm{n}=2)$ & \\
I work & $31.60 \pm 5.64(\mathrm{n}=5)$ & \\
Scholarship & $30.65 \pm 7.82(\mathrm{n}=43)$ & \\
Family support & & \\
Social skills & $29.76 \pm 6.12(\mathrm{n}=17)$ & \\
Very good & $31.25 \pm 8.47(\mathrm{n}=28)$ & \\
Good & $33.20 \pm 7.36(\mathrm{n}=5)$ & \\
Moderate & & \\
Academic performance & $26.70 \pm 5.96(\mathrm{n}=10)$ & \\
Very good & $31.90 \pm 7.93(\mathrm{n}=31)$ & \\
Good & $32.33 \pm 6.84(\mathrm{n}=9)$ & \\
Moderate & & \\
\hline p $<0.05{ }^{* *} \mathrm{p}<0.01$ & & \\
\hline
\end{tabular}

According to the study, when mean scores of beck depression and gender of the participants were compared by the t-test analysis and mean scores of beck depression and the socio-demographic characteristics among the university students were compared by the one way Anova analysis, no statistically significant difference was found.

Table 2.Comparison of Mean Score of Life Satisfaction and Socio-demographic Characteristic of University Students in TRNC

\begin{tabular}{lll}
\hline Demographic variables & $\mathbf{m} \pm \mathbf{s d}(\mathbf{n})$ & $\mathbf{F}(\mathbf{p})$ \\
\hline Gender & $24.57 \pm 8.53(\mathrm{n}=23)$ & $2.405(0.260)$ \\
Female & $22.11 \pm 6.23(\mathrm{n}=27)$ & \\
Male & & \\
Birth Place & $23.00 \pm 7.50(\mathrm{n}=9)$ & $0.009(0.991)$ \\
Cyprus & $23.26 \pm 7.30(\mathrm{n}=38)$ & \\
Turkey & $23.67 \pm 11.50(\mathrm{n}=3)$ & \\
England & & \\
Marital Status & & $2.280(0.113)$ \\
Engaged & $26.50 \pm 4.04(\mathrm{n}=4)$ & \\
In relationship & $25.50 \pm 7.84(\mathrm{n}=18)$ & \\
Not in relationship & $21.32 \pm 7.08(\mathrm{n}=28)$ & \\
\hline Reason to be in TRNC & & $0.842(0.437)$ \\
Native-born & $22.09 \pm 7.50(\mathrm{n}=11)$ & \\
\end{tabular}




\begin{tabular}{|c|c|c|}
\hline University & $23.24 \pm 7.40(n=37)$ & \\
\hline Other & $29.50 \pm 7.78(n=2)$ & \\
\hline $\begin{array}{l}\text { Class } \\
1^{\text {st }}\end{array}$ & $21.82 \pm 5.20(\mathrm{n}=17)$ & $0.325(0.822)$ \\
\hline $\begin{array}{l}2^{\text {nd }} \\
3^{\text {rd }}\end{array}$ & $\begin{array}{l}23.50 \pm 0.71(n=2) \\
23.96 \pm 8.30(n=26)\end{array}$ & \\
\hline $4^{\text {th }}$ & $24.20 \pm 10.94(\mathrm{n}=5)$ & \\
\hline Monthly income & & \\
\hline $\begin{array}{l}\text { No income } \\
1600 \text { and below }\end{array}$ & $\begin{array}{l}22.17 \pm 8.45(n=18) \\
21.56 \pm 7.30(n=18)\end{array}$ & $1.580(0.207)$ \\
\hline $\begin{array}{l}1600-3200 \\
3200 \text { or more }\end{array}$ & $\begin{array}{l}26.55 \pm 5.57(n=11) \\
27.67 \pm 1.53(n=3)\end{array}$ & \\
\hline $\begin{array}{l}\text { Whom they live } \\
\text { Alone } \\
\text { Mother/father/sibling } \\
\text { Friend }\end{array}$ & $\begin{array}{l}22.80 \pm 8.52(n=15) \\
23.60 \pm 6.37(n=15) \\
23.35 \pm 7.96(n=23)\end{array}$ & $0.058(0.981)$ \\
\hline Other & $21.50 \pm 7.78(\mathrm{n}=2)$ & \\
\hline $\begin{array}{l}\text { Economic support } \\
\text { I work } \\
\text { Scholarship } \\
\text { Family support }\end{array}$ & $\begin{array}{l}24.50 \pm 2.12(n=2) \\
26.20 \pm 8.04(n=5) \\
22.84 \pm 7.51(n=43)\end{array}$ & $0.482(0.620)$ \\
\hline $\begin{array}{l}\text { Social skills } \\
\text { Very good }\end{array}$ & $25.29 \pm 6.75(\mathrm{n}=17)$ & $3.174(0.051)$ \\
\hline $\begin{array}{l}\text { Good } \\
\text { Moderate }\end{array}$ & $\begin{array}{l}23.25 \pm 7.41(n=28) \\
16.20 \pm 6.11(n=5)\end{array}$ & \\
\hline $\begin{array}{l}\text { Academic performar } \\
\text { Very good } \\
\text { Good }\end{array}$ & $\begin{array}{l}28.20 \pm 6.12(n=10) \\
22.32 \pm 7.23(n=31)\end{array}$ & $3.201(0.050)$ \\
\hline Moderate & $20.89 \pm 7.57(n=9)$ & \\
\hline
\end{tabular}

According to the study, when mean scores of life satisfaction and gender of the participants were compared by the t-test analysis and mean scores of life satisfaction and the socio demographic characteristics among the university students were compared by the one way anova analysis, no statistically significant difference was found. There was only a statistically significant difference between variables academic performance and life satisfaction $(p=0.050)$. Whereas when further analysis Tukey HSD was made, it was found that there was not any statistically meaningful intergroup relationship between variables.

Table 3. Comparison of Mean Score of Beck depression and Life Satisfaction of the University Students in TRNC

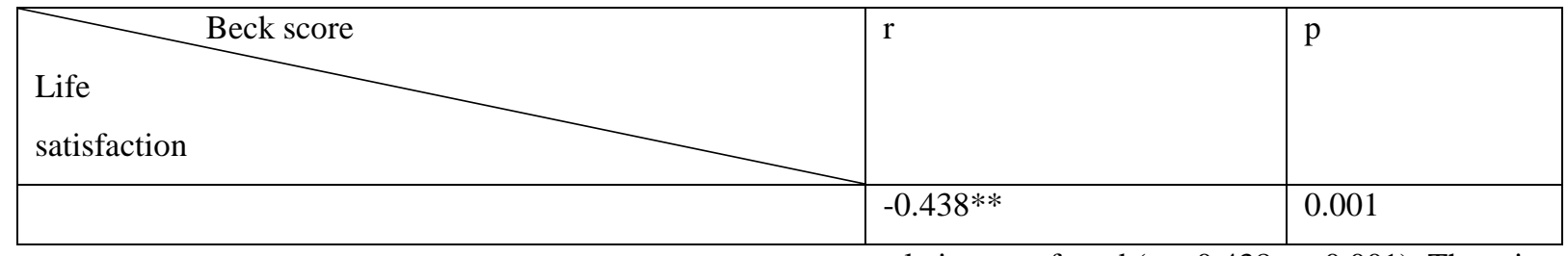

The relationship between life satisfaction level of the participants and depressive symptoms was calculated correlation was found $(\mathrm{r}=-0.438, \mathrm{p}=0.001)$. There is a with Pearson Correlation Coefficient and significant negative moderate level relationship among the 
variables. As life satisfaction decreases, depressive symptoms increase.

\section{Discussion}

The aim of this study is to investigate depressive symptoms and life satisfaction level among the university students in TRNC. Study results reveal that there is a relationship between depressive symptoms and life satisfaction. Moreover, there is also a relationship between academic performance and life satisfaction.

\section{Depression}

Similar with the present study many other studies found a relationship between depression and life satisfaction (Lewis, Dorahy, \& Schumaker, 1999; Friday, Aguwa, \& Shiweobe, 2015). As the life satisfaction of the people decreases, they become more vulnerable to depressive symptoms. The present study demonstrates that there are higher rates of depressive symptoms in male students but this difference is not statistically meaningful. On the other hand it is also found that there is no significant relationship between gender and depression among university students (Gündoğar, et. al., 2007, 14-27). Moreover another study found that lifetime and 12month prevalence of depression is nearly twice as high among women than men (Marcotte et. al., 1999, 123-31). The difference result of the study can be commented as the number of male participants is more than female ones in this study.

The present study illustrates that despite there is no statistically significant difference among marital status in depressive symptoms engaged or in a relationship participants get higher results.. Wilson and Oswald stated that break-up of the relationships has a large depressive effect (Wilson \& Oswald, 2005). Not married or not in relationship individuals usually live alone which in turn increases the risk of depression. (Ross et al 1990, 1059-78). The different finding of the study might be related to the participant population because in the present study participants are all university students and none of them are married.

Our study shows that without any statistical meaningfulness students who live alone have more depressive symptoms than the participants who live with a friend or family member. Another study indicates that Hispanics living alone report significantly higher levels of depression compared to Hispanics living with their spouse/partner. The results of the study, related to living alone and living with other people are found to be significant (Russel\&Taylor, 2009, 5-7).
Another study which investigates the association between depressive symptoms and living status (whether living alone or with others) in the elderly people illustrates that living alone was significantly associated with depressive symptoms. Moreover the absence of family living together is significantly related to depression (Fukunaga et. al., 2012, 180$85)$.

Present study illustrates without any statistical meaning that participants who stated that they have moderate relationship with family have higher scores on beck depression scale while participants who have good or very good relations have lower results. In another study it is found that there are negative directional significant difference between risk of postpartum depression risk and perceived multidimensional social support which includes family support (Yildırım et al., 2011, 31-45). Knowledge- that you are not alone and you will not give a fight with economic standards has a curative effect. Good relations serve social needs of the people.

In another study it is found that lower depressive symptoms are correlated with higher perceived family support. The findings are confirming the literature results which support the family relations importance (Alves et. al., 2014, 9-15). As Beck's triad of depression theory explains there is a constant relationship between perception of self, object and environment. The most important and first object in life is parents. If there is a negative perception of object, person will start to perceive the self negatively and thus the environment. This loop will continue as a triad.

In the present study despite there was no significant difference, participants who perceive their academic performance moderate have higher depressive symptoms when compared with the participants who perceive their academic performance good. The findings of another study of a large community sample of young adolescents, suggest that perceived academic performance is related to self-esteem, locus of control and depressive symptoms (Richardson et. al., 2005, 163-76).

\section{Life Satisfaction}

The present study demonstrates that, life satisfaction score is higher among female students than in male ones but this difference is not statistically significant. Tiefenbach and Kohlbacher found that, males are significantly less happy than females in Japan. The findings show that female participants are not only happier but also more satisfied with their lives (Tiefenbach \& Kohlbacher, 2013). In another study 
done in UK, illustrates similar average levels of life satisfaction for both men and women (Guista et. al., 2011, 1-34). The findings of the present study are related with many other studies in the past whereas it is no statistically meaningful. This may be related to the limited sample size which in turn hinders to make generalizations.

The present study demonstrates that despite there is no significant meaningful difference, life satisfaction increases as the class of the participant increase. In another study, it is found that class is not a determinant of life satisfaction whereas it is also found that hopelessness is decreased in the first class whereas it is increased at the fourth class. Moreover, other studies claims that as the age and class increases, life satisfaction decreases. On the other hand, our study found a positive correlation without any statistical meaning. This could be commented as, most of the participants are from Turkey and they are in Cyprus for education. At the fourth class they are more close to turn back to their country. This may lead to more happiness and more happiness is associated with increased life satisfaction. On the other hand, other results might be related to as the class increases, future anxiety and responsibilities increase so perception of the world is also change which can be related with life satisfaction (Ergin et. al., 2011, 4-5).

When we look at the average monthly income, as the amount of income increase, life satisfaction is also increasing whereas there is not a significant difference. . A study which includes Turkish and American university students also found that there is a positive relationship between life satisfaction and economical independence (Matheny et. al., 2002, 8197). In another study, according to the students' perception as the economic condition increases, life satisfaction also increases whereas depression, despair and anxiety level decreases (Gündoğar et. al., 2007, 19-23). The similar results in each study might be due to the relaxation and decrease focusing on economic problems can decrease level of the stress people face with and they will be more satisfied with the life as they can reach the wanted materials.

Present study illustrates that participants who live with their family or friend have higher scores on life satisfaction scale than who live alone. In another study, it is found that there is a negative correlation between loneliness and life satisfaction. In addition to this, a study demonstrates that people who live alone found to be having less belonging needs and less satisfaction level especially with the satisfaction of personal relations when compared with the people who live not alone (Mellor et. al., 2008, 213-18). The same results can be interpreted as loneliness lead to despair mode and less satisfaction as people need to entertain, talk and make sharings with another person.

It is found that there is a relationship between life satisfaction and academic performance. In another study, it is also found that there is a significant difference between perceived academic performance and life satisfaction level. Study illustrates that as the perceived academic performance level increase, life satisfaction also increases (Dost, 2007, 3243).According to another study, it is stated that there is a positive relationship between perceived school performance and life satisfaction as similar with our findings (Shek \& Li, 2015). The finding of the present study is important as it supports many other studies result. People satisfied with their talents and skills are tending to be more satisfied with their lives. There is a difference in the perception of the world between people who are satisfied with their talents or not. They are also tending to be satisfied with other features of their life.

There are small number universities in TRNC and our sample is really small to make generalizations among the country. Low participant number should be considered while interpreting the results. Application of a wider sample size with considering the all limitations such as distribution of gender, class and departments may provide more predictable and consistent results. The sample did not represent all university students because of the convenience sampling. Based on the limitation, the findings need to be replicated with more representative sample of the university students.

\section{Conclusion}

The aim of the present study is to find the relationship between depression, life satisfaction and related variables among university students in TRNC. The main result of this study is the significant relationship between depressive symptoms and life satisfaction. No significant relationship was found within depressive symptoms and socio-demographic variables. Only academic performance and life satisfaction's relationship was found as statistically meaningful as many other studies found also the same parallel results.

This study shows and gives information about the life satisfaction and depression level of the university students in TRNC however generalizations cannot be formed because of its methodology. According to changes through the social construct risk for depression is increasing day by day. It is found that one of the basic reasons for the suicide is depression. 
Moreover depression may lead or increase many medical illness. The importance of the prevalence of the depression is not widespread. It should be transferred to many people as possible because of the disorder's harmful consequences. The findings of the study are yelling some useful information about the related topics whereas the limitations of the study should be considered while interpreting the results. To decrease these limitations such as mapping problems with socio-demographic variables there is a need for more systematic researches. With proper prevention programs depression risk and suicide could be decreased.

\section{References}

Alves G., Baptisa, M., \& Santos, A. (2014). Relation between depression, family support and stress at work in undergraduates. International Journal of Psychology and Behavioral Sciences, 4(1), 9-15.

Ceyhan, A., Ceyhan, E., \& Kurtyılmaz, Y. (2009). Investigation of university students depression. Eurasian Journal of Educational Research, 36,75-90.

Diener, Ed, \& Suh, E. (1997). Measurıng quality of life: Economic, social and subjective indicators. Social Indicators Research. 30(1),189-216.

Diener, Ed. (1984). Subjective well-being. Psychological Bulletin, 95(3), 542-575.

Dost, M. (2007). Üniversite öğrencilerinin yaşam doyumunun bazı değişkenlere göre incelenmesi. Pamukkale Üniversitesi Eğitim Fakültesi Dergisi, 2(22), 132-143.

Erturan, İ., Aktepe, E., Kocaman, O., Sönmez, Y., Başak, P.Y., Ceyhan, A.M., \& Akkaya, V.B. (2014). Akneli ergenlerin yaşam kalitesi, yalnızlık ve yaşam doyumu düzeylerinin değerlendirilmesi. Türkderm, 48(4), 172-6.

Friday, O., Aguwa, E., Schiweobi, C. (2015). Life Satisfaction, Self Esteem and Depression in a Sample of Nigerian Adolescents. International Neuropsychiatric Disease Journal, 5(3).

Fukunaga, R., Abe, Y., Nakagawa, Y., Koyama, A., Fujise, N., \& Ikeda, M. (2012). Living alone is associated with depression among the elderly in a rural community in Japan. Psychogeriatrics.12(3), 179-185.

Guista, D., Jewell, M.S., \& Kambhampati, U.S. (2011). Gender and life satisfaction in the UK. Feminist Economics, 17(3),1-34.

Gündoğar, D., Gül, S., Uskun, E., Demirci, S., \& Keçeci, D. (2007). Üniversite öğrencilerinde yaşam doyumunu yordayan etkenlerin incelenmesi. Klinik Psikiyatri, 10, 1427.

Karaca, S., \& Aşkın, R. (1995). Depresyonla Başaçıkma Ölçeği: Geçerlilik ve Güvenirlik Çal 1şması. Düşünen Adam, 8(3), 24-30.

Lewis, C., Dorahy, M., \& Schumaker, J. (1999). Depression and Life Satisfaction Among Northern Irish Adults. The Journal of Social Psychology, 139(4), 533-5.

Marcotte, E., Virgina, D., \& Redmon, P. (1999). Prevalence and patterns of major depressive disorder in the United States Labor Force. The Journal of Mental Health Policy and Economics J. Mental Health Policy Econ, 2, 123-131.
Matheny, K., Curlette, W., Aysan, F., Herrington, A., Gfroeroer, C., Thompson, D., \& Hamarat, E. (2002). Coping resources, perceived stres and life satisfaction among Turkish and American university students. Int $\mathbf{J}$ Stress Manag, 9(2), 81-97.

Mellor, D., Stokes, M., Firth, L., Hayashi, Y., \& Cummins, R. (2008). Need for belonging, relationship satisfaction, loneliness, and life satisfaction. Science Direct Journals, 45(3), 213-218.

Murray, C.J., \& Lopez, A.D. (1996). Evidence based health policy lessons from the Global Burden of Disease. Study Science, 274(528), 740-743.

Özkan, Ö. (2013). İnternet kullanımıyla ilgili değişkenlerin cinsiyet, kişilik özellikleri, yaşam doyumu ve bağlanma stilleri açısından incelenmesi. (Yüksek Lisans Tezi). T.C. Ankara Üniversitesi Sosyal Bilimler Enstitüsü Psikoloji Anabilim Dalı, Ankara.

Öztürk, O., \& Uluşahin, A. (2015). Ruh Sağlığı ve Bozuklukları. Ankara: Nobel T1p Kitabevi.

Richardson, A., Bergen, H., Martin, G., Roeger, L., \& Allison, S. (2005). Perceived academic performance as an indicator of risk of attempted suicide in young adolescents. Archives of Suicide Research, 9(2), 163-176.

Ross, C., Mirowsky, J., \& Goldsteen, K. (1990). The impact of the family on health: the decade in review. Journal of Marriage and the Family, 52, 1059-1078.

Russel, D., \& Taylor, J. (2009). Living alone and depressive symptoms: The influence of gender, physical disability, and social support among Hispanic and NonHispanic older adults. Journal of Gerontology, 64(1), 95104.

Shek, D., \& Li, X. (2015). Perceived school performance, life satisfaction, and hopelessness: A 4-year longitudinal study of adolescents in Hong Kong. Soc Indic Res, 126(2), 921-34.

Sundriyal, R., \& Kumar, R. (2013). Depression and life satisfaction among married \& unmarried women. IOSR Journal of Humanities And Social Science, 16(3), 33-36.

Tiefenbach, T., \& Kohlbacher, F. (2013). Happiness and life satisfaction in Japan by gender and age. German Institute for Japanese Studies.

WHO. (2016). Depression. Accessed 13 August 2016. http://apps.who.int/mediacentre/factsheets/fs369/en/index.h tml 
Wilson, M., Andrew, C., \& Oswald, J. (2005). How does marriage affect physical and psychological health? A survey of the longitudinal evidence. Institute for the Study of Labor.

Yetim, Ü. (1991). Kişisel projelerin organizasyonu ve örüntüsü açısından yaşam doyumu. (Unpublished Phd Thesis). Ege Üniversitesi Sosyal Bilimler Enstitüsü, İzmir.
Yetim, Ü. (2003). The impacts of individualism/collectivism, self-esteem, and feeling of mastery on life satisfaction among the Turkish university students and academicians. Social Indicators Research, 61(3), 297-317.

Yıldırım, A., Hacıhasanoğlu, R., \& Karakurt, P. (2011). The relationship between postpartum depression and social support and affecting factors. International Journal of Human Sciences, 8(1), 31-45. 